\title{
Endemicity of Dengue with Density Figure and Maya Index in Bengkulu City, Indonesia
}

Dessy Triana $^{1,2 \star}$, Lala Foresta Valentine Gunasari ${ }^{1}$, Helmiyetti Helmiyetti ${ }^{3}$, Martini Martini ${ }^{4}$, Ari Suwondo ${ }^{4}$, Muchlis A. U. Sofro ${ }^{5}$, Miftahul Haniyah ${ }^{1}$, Meilia Andini ${ }^{1}$

${ }^{1}$ Department ofParasitology, Faculty of Medicine and Health Sciences, Universitas Bengkulu, Bengkulu, Indonesia; ${ }^{2}$ Doctoral Program of Medicine and Health Sciences, Faculty of Medicine, Universitas Diponegoro, Semarang, Indonesia; ${ }^{3}$ Department of Biology, Faculty of Mathematics and Natural Sciences, Universitas Bengkulu, Bengkulu, Indonesia; ${ }^{4}$ Department of Occupational Health and Safety, Faculty of Public Health, Universitas Diponegoro, Semarang, Indonesia; ${ }^{5}$ Department of Internal Medicine, Faculty of Medicine, Universitas Diponegoro, Semarang, Indonesia

\section{Abstract} Edited by: Sasho Stolesk
Citation: Triana D, Gunasari LFV, Helmiyetti H, Martini M Suwondo A, Sofro MAU, Haniyah M, Andini M. Endemicity of Dengue with Density Figure and Maya Index in
Bengkulu City, Indonesia. Open-Access Maced J Med Sci. 2021 Dec 13; 9(E):1504-1511. https://doi.org/10.3889/oamjms.2021.7718 Keywords: Dengue; Aedes spp.; Ovitrap index; House index; Container index; Breteau index; Maya index; Correspondence: Dessy Triana, Doctoral Program of Medicine and Health Sciences, Faculty of Medicine, Universitas Diponegoro, Indonesia. E-mail: dessy.triana@unib.ac.id o Received: $27-$ Oct-202 Revised: 28-Nov-2021 Copyright: @ 2021 Dessy Trian, Copyright: ๑ 2021 Dessy Trian Martini Martini, Ari Suwondo, Muchlis A U Sofro, Miftahul Haniyah, Meilia Andin
unding: This study was supported by the Faculty of Medicine and Health Sciences, Bengkulu University Competing Interests: The authors have declared that no Open Access: This is an open-access article distributed under the terms of the Creative Commons Attribution-
BACKGROUND: One of the factors contributing to dengue's endemicity is the density of the dengue vector, namely, Aedes aegypti as the primary vector and Aedes albopictus as the secondary vector. Bentiring and Kandang Limun villages are high endemic areas of dengue.

AIM: This study aimed to determine the relationship between dengue endemicity and density figure (DF) and Maya index (MI) in Bentiring and Kandang Limun villages, Bengkulu city.

METHODS: This study used a cross-sectional design. The sampling technique used proportionate stratified sampling. The sampling refers to the guidelines for denque entomology surveys according to the WHO 1999 criteria. A total of 400 ovitraps were installed, 200 ovitraps inside the house and 200 ovitraps outside the house.

RESULTS: The results showed that Bentiring and Kandang Limun villages had a high risk of dengue transmission based on entomological parameters, namely, ovitrap index (OI) $56 \%$ and $55 \%$ (DF 6), house index (HI) $45 \%$ and $44 \%$ (DF 6), container index (CI) $23 \%$ and $23 \%$ (DF 6), and BI 96\% and 120\% (DF 7 and 8). The areas have a high risk of dengue transmission based on the $\mathrm{Ml} 71 \%$ and $76 \%$, respectively. There is a relationship between dengue endemicity and entomological index in Bentiring and Kandang Limun villages, Bengkulu city, with a significance value $(p=0.000)$ and a powerful correlation $(r=1.000)$

CONCLUSION: There is a relationship between dengue endemicity and the $\mathrm{MI}$ in Bentiring village and Kandang Limun village, Bengkulu city, with a significance value $(p=0.014$ and 0.058$)$ and a powerful correlation $(r=0.920$ and $r=1.000)$, respectively. The entomological index and DF are predictors for dengue prevention and control environment to minimize mosquito breeding sites and reduce disease transmission.

\section{Introduction}

Dengue is an infectious disease of the dengue virus transmitted to humans through the bite of the Aedes sp., namely, Aedes aegypti (Ae. aegypti) as the primary vector and Aedes albopictus (Ae. albopictus) as a secondary vector [1]. Dengue infection worldwide is estimated at 50 million cases with 22.000 deaths every year, and 2.5 billion people are living in dengue infection endemic areas [2]. Indonesia is reported as the $2^{\text {nd }}$ country with the largest dengue cases among 30 endemic areas of Southeast Asian countries [3].

Based on data reported by the Indonesian Ministry of Health in 2016, the number of dengue cases in Indonesia increases every year. Outbreaks of dengue in 2016 occurred in 12 regencies/cities, one of which was Bengkulu city. In 2018, Bengkulu Province was the third highest nationally in Indonesia [4], [5]. Muara Bangkahulu district is one of the districts with the highest number of dengue cases in Bengkulu city, namely, 49 cases in 2017 and 57 cases in 2019. The village with the highest incidence of dengue fever in Muara Bangkahulu district is Bentiring village, followed by Kandang Limun village [6]

Strategies for the prevention and control of dengue fever can be carried out by vector control at both the larval and adult stages [2], [7]. Prevention of the incidence of dengue requires data on the population density of Aedes sp., which can be measured using entomological indicators, namely, the larva index (LI), which consists of the container index $(\mathrm{Cl})$, house index $(\mathrm{HI})$, and Breteau index $(\mathrm{BI})$. These calculations were compared and categorized based on the vector density number or density figure(DF)from the WHO. The category of the risk of dengue transmission is mild, moderate, and severe based on the DF. The entomological index is very effective in monitoring vulnerable areas where dengue cases often occur to anticipate the emergence of new cases [8]. Taslisia research stated that the 
entomological survey in Salido Village, IV Jurai District, Pesisir Selatan Regency obtained HI 57\%, Cl 22.04\%, $\mathrm{BI} 123 \%$, and larval density of $\mathrm{Ae}$. aegypti are at highdensity levels. This research is similar to the research conducted by Widjajanti that the results of the study of Jembrana and Karangasem districts are included in the medium-risk category of dengue transmission, while Badung district is included in the category of high risk of dengue transmission [9], [10].

The ovitrap index (OI) is also used to add information on the egg-laying activity of adult female mosquitoes inside and outside the house. The OI can be an alternative to detect mosquitoes from breeding places not accessible from the surrounding area [11]. The OI is used to add information from larval surveys such as the $\mathrm{HI}$, Breteau index (BI), and $\mathrm{Cl}$ [12]. Wijayanti's research found that the highest OI data were detected at $97.56 \%$. These results can provide information that almost all areas surveyed are infested with mosquitoes and the high risk of dengue transmission in the area [13].

The emergence of dengue through the concept Epidemiological Triangle proposed by Gordon and Le Richt, namely, that dengue occurs due to an imbalance between the host, the agent, and the environment [14]. $A$ e. aegypti and $A$ e. albopictus transmit the dengue virus. There is no information regarding the density of Aedes sp. which can describe the risk of transmission of dengue virus by Aedes sp. Information on the density of Aedes sp. can be searched using the entomological index, namely, LI, OI, and pupae index. This study aimed to determine the relationship between DHF endemicity and the entomological index in Bentiring village and Kandang Limun village, Bengkulu city. This information can identify the potential risk of transmission and strengthen environmental health to help control dengue effectively.

\section{Methods}

This research has been approved by the Bengkulu University Medical Ethics and Health Sciences Commission No. 224/UN30.14.9/LT/2020. The research design used a cross-sectional study with analytical observational methods. The study was conducted in Bentiring and Kandang Limun villages in October-November 2020. The research location was in the Community Association (RW) in the village with the highest, moderate, and lowest incidence of dengue based on secondary data from the Health Office of Bengkulu City in 2019 to 2020.

The survey sample consisted of 100 houses (100 ovitraps indoor and 100 ovitraps outdoor) in each village. The sample was taken using the proportionate stratified sampling technique, namely, 45 samples of houses in areas with high cases, 35 samples in areas with moderate cases, 20 houses in areas with low cases, and installed ovitrap. The research population is all residents' houses in Bentiring village and Kandang Limun village. The sampling method refers to the guidelines for dengue entomology surveys according to the WHO 1999 criteria, using the number of houses and the $\mathrm{HI}$ data at research site (Table 1).

Table 1: Number of houses inspected by $\mathrm{HI}$

\begin{tabular}{llll}
\hline Number of buildings & $\mathrm{HI}$ & & \\
\cline { 2 - 4 } & $>1 \%$ & $72 \%$ & $>5 \%$ \\
\hline 100 & 95 & 105 & 45 \\
200 & 155 & 117 & 51 \\
300 & 189 & 124 & 54 \\
400 & 211 & 129 & 56 \\
500 & 225 & 138 & 57 \\
1000 & 258 & 143 & 58 \\
2000 & 277 & 147 & 59 \\
5000 & 290 & 148 & 59 \\
10,000 & 294 & 149 & 59 \\
Unlimited & 299 & &
\end{tabular}

Data from larvae and pupa surveys were calculated in entomological indices, namely, the $\mathrm{LI}$ $(\mathrm{HI}, \mathrm{Cl}$, and $\mathrm{BI}$ ) and Maya index (MI). The relationship between DHF endemicity and the entomological index was analyzed using the gamma correlation test to measure the significance of the relationship ( $p$-value) and the strength of the correlation ( $r$ ) between two variables with an ordinal-ordinal data scale [15]. The entomological index is calculated using the following formula [2], [16]:

$$
\begin{aligned}
& \text { OI (WHO, 2011) } \\
& \text { OI= } \frac{\text { Number of Ovitrap with egg }}{\text { Number of Ovitrap analysed }} \times 100 \%
\end{aligned}
$$

\section{LI (WHO, 2011)}

$$
\begin{aligned}
& \mathrm{HI}=\frac{\text { Number of houses infested }}{\text { Number of house inspected }} \times 100 \% \\
& \mathrm{CI}=\frac{\text { Number of positive containers }}{\text { Number of containers inspected }} \times 100 \% \\
& \mathrm{BI}=\frac{\text { Number of positive containers }}{\text { Number of houseinspected }} \times 100 \%
\end{aligned}
$$

MI (Service, 2008)

$B R I=$

Number of Controllable site inside the houses $\sum$ Average number of containers inside the houses $\mathrm{HRI}=$

Number of disposable sites inside the houses $\overline{\sum \text { Average number of containers inside the houses }}$

The MI analysis is carried out by categorizing the observed containers into controllable containers and disposable containers. The hygiene risk index $(\mathrm{HRI})$ and breeding risk index (BRI) can be calculated 
for each house inspected from these two categories of containers. The two indicators (HRI and BRI) of each house are categorized into three, namely, high, medium, and low, forming a $3 \times 3$ table. The grouping of categories and a $3 \times 3$ (tertile) table is shown in Table 2 . The combination of the categorization of the two indicators in the detailed table is called the MI, which is also categorized into three, namely, low, medium, and high [16].

Table 2: $3 \times 3$ matrix of BRI and HRI components on MI

\begin{tabular}{llll}
\hline & BRI & Medium & High \\
\cline { 2 - 4 } & Low & Low & Medium \\
\hline HRI & Low & Medium & High \\
Low & Low & High & High \\
Medium & Medium & High & Breeding risk indicator, HRI: Hygiene risk indicator, Ml: Maya index.
\end{tabular}

The OI for Aedes sp. can be classified into four levels, which reflect the level of Aedes sp. infestation, namely, Level $1 \mathrm{Ol}<5 \%$ (mosquito attack is not widespread in the surveyed area), Level $25 \%$ OI $<20 \%$ (mosquito attack is slightly more area in the surveyed area), Level 3 20\% Ol< 40\% (mosquito attack > 1/5 of the surveyed area), and Level 4 Ol 40\% (almost half of the surveyed area is infested with mosquitoes) [17].

Table 3: Larval/pupae density according to the WHO

\begin{tabular}{llll}
\hline DF & HI & Container index & Breteau index \\
\hline 1 & $1-3$ & $1-2$ & $1-4$ \\
2 & $4-7$ & $3-5$ & $5-9$ \\
3 & $8-17$ & $6-9$ & $10-19$ \\
4 & $18-28$ & $10-14$ & $24-34$ \\
5 & $29-37$ & $15-20$ & $35-49$ \\
6 & $38-49$ & $21-27$ & $50-74$ \\
7 & $50-59$ & $28-31$ & $75-99$ \\
8 & $60-76$ & $32-40$ & $100-199$ \\
9 & $>77$ & $>41$ & $>200$ \\
\hline \multicolumn{2}{l}{ Source: WHO, 2003. DF: Density figure } &
\end{tabular}

The World Health Organization determines the density of larvae or pupae (DFs) in three categories, is shown in Table 3, namely: DF 1 (Low larva/pupa density), DF 2-5 (medium larva/pupa density), and DF 6-9 (high larval/pupae density) [18]. The pupae/person index has a DHF transmission threshold value of 0.5 1.5 with an optimal air temperature of $28^{\circ} \mathrm{C}$ [19]. The percentage of larvae index $(\mathrm{HI}, \mathrm{Cl}$, and $\mathrm{BI})$ interpreted the level of risk of transmission according to the criteria in Table 4.

Table 4: Categories of entomological parameters on the risk of dengue transmission

\begin{tabular}{ll}
\hline Entomological parameter & Transmission risk \\
\hline $\mathrm{HI}>5 \%$ & High risk \\
$\mathrm{HI}<5 \%$ & Low risk \\
$\mathrm{Cl}>10 \%$ & High risk \\
$\mathrm{Cl} \leq 10 \%$ & Low risk \\
$\mathrm{Bl} \geq 50 \%$ & High risk \\
$\mathrm{Bl}<50 \%$ & Low risk \\
\hline Source: $\mathrm{WHO}, 2003 . \mathrm{Cl}:$ Container index, $\mathrm{Hl}:$ House index, Bl: Breteau index. &
\end{tabular}

\section{Results}

The incidence rate (IR) of dengue in Bentiring village in 2020 was recorded at 7.6/10,000 residents in Bentiring village and 13/10,000 residents in Kandang
Limun village [20]. According to Dinata, regions with an $\mathrm{IR}>5 / 10,000$ population are urban villages that experience dengue fever with high endemicity [21]. In this study, 400 ovitraps were installed in both villages. There were 113 eggs that positive ovitraps (56\%) of the 200 installed in Bentiring village $(\mathrm{OI}=56 \%)$ included in Level 4. Kandang Limun village had 110 eggs that positive ovitraps (55\%) of the 200 installed ovitraps, thus OI $=55 \%$ (level 4 ). The results of the complete OI are shown in Table 5.

Table 5: Ol in Bentiring and Kandang Limun villages, Bengkulu city, Indonesia

\begin{tabular}{|c|c|c|c|c|c|c|c|c|c|c|}
\hline \multirow[t]{2}{*}{ Location } & \multicolumn{3}{|c|}{ Indoor } & \multicolumn{3}{|c|}{ Outdoor } & \multicolumn{3}{|l|}{ Total } & \multirow{2}{*}{$\begin{array}{l}\text { Classification } \\
\text { (level) }\end{array}$} \\
\hline & $(+)$ & $(-)$ & Total & $(+)$ & $(-)$ & Total & Ovitrap & $(+)$ & OI (\%) & \\
\hline Bentiring & 49 & 51 & 100 & 64 & 36 & 100 & 200 & 113 & 56 & 4 \\
\hline Kandang & 38 & 62 & 100 & 72 & 28 & 100 & 200 & 110 & 55 & 4 \\
\hline Limun & & & & & & & & & & \\
\hline
\end{tabular}

A sample of 100 houses in Bentiring village contained 45 positive larval houses $\mathrm{HI}$ in Bentiring village was $45 \%$. Of the 419 containers examined, 96 containers were positive for larvae, and 323 were not found with mosquito larvae, with a $\mathrm{Cl}$ value of $23 \%$ and the $\mathrm{BI}$ value of $96 \%$, respectively. The entomological parameters $(\mathrm{HI}, \mathrm{Cl}$, and $\mathrm{BI})$ were converted to obtain the DF value. The entomological parameters in Bentiring village had $\mathrm{HI}$ values of $45 \%$ (DF 6), $\mathrm{Cl} 23 \%$ (DF 6), and BI 96\% (DF 7); in Kandang Limun village had $\mathrm{HI}$ values $44 \%$ (DF 6), Cl 22\% (DF 6), and BI 120\% (DF 8). The result is shown in Table 4.

The water reservoirs inspected in Bentiring village were 419 containers, of which 96 containers (22.9\%) were positive for Aedes sp. There were 348 controllable sites (CSs) and 67 containers (19\%) positive for Aedes sp. The container with the highest number of positive larvae is a bucket with 193 and 47 positive (24\%). In contrast, the number of disposable sites (DSs) is lower than CS, 71 containers with 29 containers (40\%) positive for larvae. The type of DS with the highest number of containers is used buckets with 55 and 25 positive (45\%). Similarly, in Kandang Limun village, 508 containers were found with 120 positive containers for Aedes sp. larvae (23.6\%). The percentage of CS $(97.6 \%)$ was greater than that of DS $(2.4 \%)$, the percentage of larval positive CS containers was $23.9 \%$, and the percentage of DS positive containers was $25 \%$. The distribution of the types of containers that are positive for larvae is shown in Figure 1.

In this study, mosquito larvae were identified to distinguish Aedes sp. from other mosquito species. Identification of larvae used the single larvae method, namely, by taking one larva in each container containing larvae for further identification under a light microscope. This study identified the larvae of Ae. aegypti (5\% and $19 \%)$ and Ae. albopictus (95\% and $81 \%$ ) in Bentiring and Kandang Limun villages, respectively. This result aligns with Bentiring village and Kandang Limun village, which are still surrounded by plantations. The habitat of Ae. albopictus is the most common in settlements on the outskirts of forests and plantations [22]. 
The results of the relationship analysis between dengue endemicity and larvae index $(\mathrm{HI}$, $\mathrm{Cl}$, and Breteau index) in Bentiring and Kandang Limun villages obtained $p=0.000$ and correlation strength $(r)=1.000$, which means statistically. There is a significant relationship with a powerful correlation between dengue endemicity and larvae index $(\mathrm{HI}, \mathrm{Cl}$, and Breteau index) (Table 6).

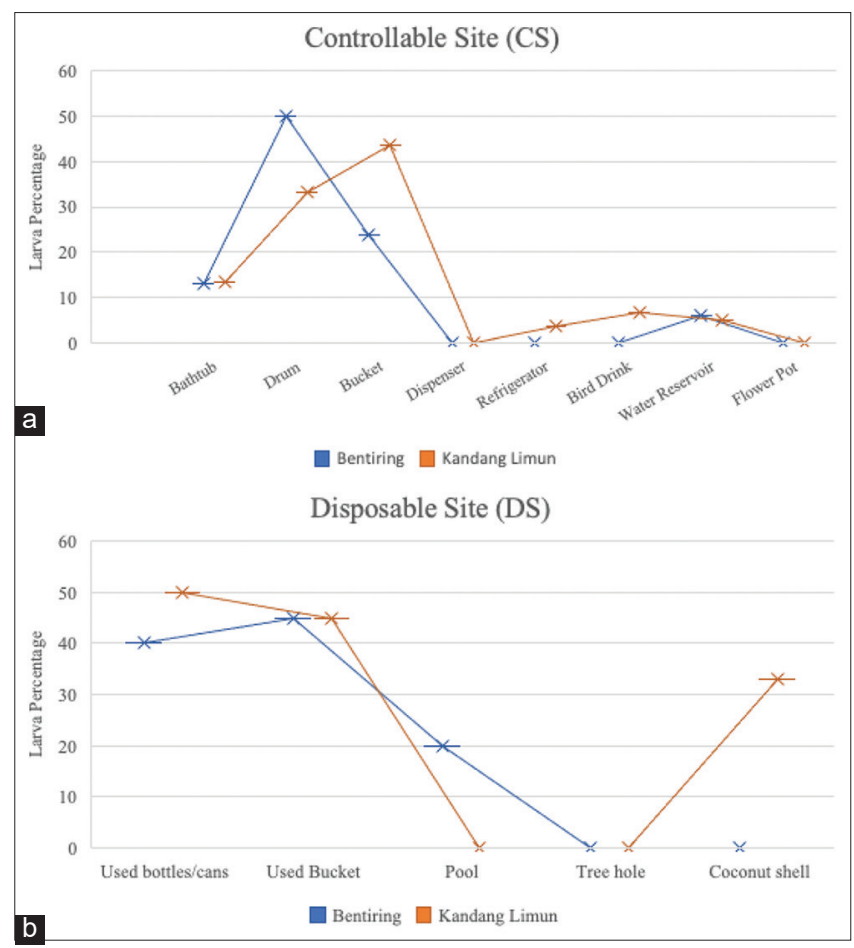

Figure 1. ( $a$ and b) Types of positive containers for Aedes sp. Larva

MI classified 100 houses sampled in the two villages in the form of $\mathrm{HRI}$ and BRI. In Kandang Limun village, the highest calculation is in the medium category, with an $\mathrm{HRI}$ value of $84 \%$ and a $\mathrm{BRI}$ value of $77 \%$. Bentiring village has an $\mathrm{HRI}$ value of $77 \%$ in the medium category and BRI $61 \%$ in the high category. The data are shown in Table 6.

Table 6: Association of dengue endemicity with $\mathrm{OI}, \mathrm{HI}$, and $\mathrm{CI}$

\begin{tabular}{|c|c|c|c|c|c|c|}
\hline \multirow[t]{3}{*}{ Ovitrap } & \multicolumn{4}{|c|}{$\mathrm{OI}$} & \multirow[t]{3}{*}{$p$-value } & \multirow[t]{3}{*}{$r$} \\
\hline & \multicolumn{2}{|c|}{ Bentiring village } & \multicolumn{2}{|c|}{ Kandang Limun village } & & \\
\hline & $\mathrm{n}$ & Ol (\%) & $\mathrm{n}$ & Ol (\%) & & \\
\hline Positive & 113 & 56 & 110 & 55 & 0.000 & 1.000 \\
\hline Negative & 87 & & 90 & & & \\
\hline Total & 200 & & 200 & & & \\
\hline \multirow[t]{3}{*}{ House } & \multicolumn{4}{|c|}{ House index } & $p$-value & $r$ \\
\hline & \multicolumn{2}{|c|}{ Bentiring village } & \multicolumn{2}{|c|}{ Kandang Limun village } & & \\
\hline & $\mathrm{n}$ & $\mathrm{HI}(\%)$ & $\mathrm{n}$ & $\mathrm{HI}(\%)$ & & \\
\hline Positive & 45 & 45 & 44 & 44 & 0.000 & 1.000 \\
\hline Negative & 55 & & 56 & & & \\
\hline Total & 100 & & 100 & & & \\
\hline DF & & 6 & & 6 & & \\
\hline \multirow[t]{3}{*}{ Container } & \multicolumn{4}{|l|}{$\mathrm{Cl}$} & $p$-value & $r$ \\
\hline & \multicolumn{2}{|c|}{ Bentiring village } & \multicolumn{2}{|c|}{ Kandang Limun village } & & \\
\hline & $\mathrm{n}$ & $\mathrm{Cl}(\%)$ & $\mathrm{n}$ & $\mathrm{Cl}(\%)$ & & \\
\hline Positive & 96 & 22.9 & 120 & 23.6 & 0.000 & 1.000 \\
\hline Negative & 323 & & 388 & & & \\
\hline Total & 419 & & 508 & & & \\
\hline DF & & 6 & & 6 & & \\
\hline \multirow[t]{3}{*}{ Container } & \multicolumn{4}{|c|}{ Breteau index } & $p$-value & $\mathrm{r}$ \\
\hline & \multicolumn{2}{|c|}{ Bentiring village } & \multicolumn{2}{|c|}{ Kandang Limun village } & & \\
\hline & $\mathrm{n}$ & $\mathrm{BI}(\%)$ & $\mathrm{n}$ & $\mathrm{BI}(\%)$ & & \\
\hline Positive & 113 & 96 & 110 & 120 & 0.000 & 1.000 \\
\hline Negative & 87 & & 90 & & & \\
\hline Total & 200 & & 200 & & & \\
\hline DF & & 7 & & 8 & & \\
\hline
\end{tabular}

The relationship between dengue endemicity and $\mathrm{MI}(\mathrm{HRI}$ and $\mathrm{BRI})$ in Bentiring and Kandang Limun villages obtained $p=0.058$ and 0.014 and correlation strength $(r)=0.920$ and 1.000 , respectively. A significant relationship with a powerful correlation between Dengue Endemicity with Maya Index.

Table 7: Association of dengue endemicity with MI

\begin{tabular}{lllllll}
\hline Areas & Category & HRI & BRI & Maya index (\%) & p-value & r \\
\hline Bentiring & Low & 0 & 13 & 1 & 0.058 & 0.920 \\
& Medium & 77 & 26 & 28 & & \\
& High & 23 & 61 & 71 & & \\
\multirow{5}{*}{ Kandang Limun } & Total & 100 & 100 & 100 & 0.014 & 1.000 \\
& Low & 0 & 8 & 8 & & \\
& Medium & 84 & 77 & 76 & & \\
& High & 16 & 15 & 16 & & \\
& Total & 100 & 100 & 100 & & \\
\hline HRI: Hygiene risk index, BRI: Breeding risk index, MI: Maya index. & & & \\
\multicolumn{7}{l}{}
\end{tabular}

\section{Discussion}

The Ol of Bentiring village describes the high mosquito population density in both areas with an OI result of $40 \%$ belonging to Level 4 . This Ol provides information that almost part of the surveyed area is infested with Aedes sp. Research conducted by Wahyuningsih reported that the total number of eggs in areas with high dengue cases was the most compared to areas with low dengue cases. Although the egg phase still has to go through several stages to become an adult mosquito, to become a competent vector for transmitting the dengue virus, the OI number can describe the density of mosquitoes in producing eggs and laying their eggs on the surface of the container. The level of mosquito density is not always relevant to describe the number of dengue cases in an area. However, the description of mosquito density in an area can illustrate the precautions that must be taken to prevent and control the transmission of dengue disease [13], [23], [24].

Positive ovitraps outside the home had a higher percentage than those inside the home (Table 3). Based on these results, Aedes sp. tend to lay their eggs in containers outside the house, which means that water reservoirs outside the home can be a breeding ground for mosquitoes, primarily used items outside the home such as used buckets and cans that will fill with water when it rains. Hence, it has the potential as a breeding ground for mosquitoes. Eradication of mosquito nests must continue to be encouraged to minimize water reservoirs used as breeding places for mosquitoes. These results are in line with the research of Judhi in 2019 that the Ol value outside the home has a higher percentage than inside the house, with the Ol value in Makassar city, which is $66.7 \%$, the mosquito eggs are higher outside the house $(44.44 \%)$ compared to inside the house $(37.22 \%)$. These results are in line with the research of Wijayanti which states that the OI value outside the home has a higher percentage than inside the house in Kranji village, the working area of the East Purwokerto Health Center II. The number of eggs 
outside the house was higher related to the mosquito species, namely, Ae. albopictus, which has a habitat outside the house [13], [25].

The relationship between DHF endemicity and $\mathrm{OI}$ in Bentiring village is statistically significant with $p$ $=0.000$ and correlation strength $(r)=1000$, which indicates a powerful correlation. Statistically, there is a significant relationship with a powerful correlation between DHF endemicity and OI, and this result is in line with the Ol survey value in both outputs. In the area surveyed, there are many adult mosquitoes, so they have the potential for dengue transmission.

The larval survey was used to obtain the value of the $\mathrm{LI}$, which consisted of the $\mathrm{HI}, \mathrm{Cl}$, and Breteau index. The $\mathrm{HI}$ in Bentiring village and Kandang Limun village $45 \%$ and $44 \%$ is equivalent to DF 6 , which means that Bentiring village has a high density of Aedes sp. larvae. Determination of the risk of transmission based on $\mathrm{HI}$ values $>5 \%$ is included in the high $\mathrm{HI}$ criteria, meaning that the density of larvae in Bentiring and Kandang Limun villages has a high risk of transmission dengue disease. One of the factors causing the high value of $\mathrm{HI}$ in both villages in the community's behavior and participation, which is still lacking in mosquito breeding eradication (PSN) activities. According to the Indonesian Ministry of Health, the 3M Plus PSN program includes draining, closing, utilizing used goods, carrying out larvicidation, biological control by raising larvae eating fish, and personal protective equipment as mosquito nets and mosquito repellents.

The study by Triana in Bengkulu city showed that the entomological parameters for $\mathrm{HI}, \mathrm{Cl}$, and container pupa index (CPI) in Jalan Gedang village and Lingkar Barat village were estimated: $7 \%, 12 \%$ for $\mathrm{HI}$ and $1.97 \%, 3.43 \%$ for $\mathrm{Cl}$, and $5 \%, 2 \%$ for $\mathrm{CPI}$, respectively [26]. A similar study by Khairunnisa in the city of Semarang obtained an $\mathrm{HI}$ value of $44 \%$ equivalent to DF 6 , which means that it has a high mosquito density so that it has a high enough risk for transmission of dengue disease [23]. Another similar study by Cahyani (2019) in Magetan district, Magetan Regency, obtained an $\mathrm{HI}$ value of $53 \%$ who had high $\mathrm{HI}$ criteria and had a high risk of DHF incidence [27]. Research conducted by Anggraini showed a significant relationship between the presence of larvae in water reservoirs and the incidence of dengue fever in Koduru village, Surabaya city [28].

The $\mathrm{Cl}$ value in Bentiring and Kandang Limun villages is $23 \%$ or equivalent to DF 6 , has a high larval density, and a high risk of DHF transmission, which means Bentiring sighs (Table 4). According to the WHO, the $\mathrm{Cl}$ describes the number of positive water reservoirs for larvae from the number of water reservoirs examined. The $\mathrm{Cl}$ is an entomological indicator used to determine the risk of transmission based on mosquito density by adding up the positive larval containers divided by the total number of containers and multiplied by $100 \%$. If an area has a $\mathrm{Cl}>5 \%$, it has a high risk, whereas if the $\mathrm{Cl}$ is less than $5 \%$, it has a low risk of transmitting dengue disease [18]. The results of this study are in line with Taslisia's research (2017) which found that the $\mathrm{Cl}$ value in Salido village, IV Jurai, Pesisir Selatan district was $22.04 \%$, including the category of having high risk. Another research by Firmansyah showed a $34 \% \mathrm{Cl}$ value in Patunas Village, Tanjung Jabung Barat Regency, equivalent to DF 8, which has a high larval density and has a high risk of dengue transmission [29].

Container characteristics can also affect the presence of Aedes sp. The container characteristics include the material, the location, the presence of the cover, the volume, the water source, and the color of the container. In addition, Agustin mentions that Ae. aegypti can breed in clean water that is not in contact with groundwater. The mosquito vector Aedes sp. from the egg phase to the imago can be influenced by biotic or abiotic environmental factors [30]. Supporting research results by Sumantri showed a significant relationship between the habit of closing the landfill and the incidence of dengue [31], [32].

The research results in Bentiring and Kandang Limun villages found that the $\mathrm{BI}$ values were $96 \%$ (DF 7) and 120\% (DF 8). This research illustrates that the two villages have a high larval density and have a high risk of DHF transmission. The Breteau index is an entomological indicator used to determine the risk of transmission based on mosquito density by determining the number of positive water reservoirs for Aedes sp. with the number of houses surveyed. According to the $\mathrm{WHO}$, a $\mathrm{BI}$ value $>50 \%$ has a high risk and a $\mathrm{BI}<50 \%$ low risk for DHF transmission. According to the $\mathrm{WHO}$, a $\mathrm{BI}$ value $>50 \%$ has a high risk for dengue transmission [18], [33]. Supporting research by Taslisia, the $\mathrm{BI}$ value was $123 \%$ in the Salido Pesisir Selatan village, and the research of Novita in Korong Gadang obtained a $\mathrm{BI}$ value of $102 \%$ [3], [9].

In Kandang Limun village, there were 496 controlled containers (CS), with 117 of them (23.9\%) positive for larvae. In comparison, the uncontrolled containers (disposable site) were 12 containers, with 3 of them (25\%) positive for Aedes sp. larvae. The percentage of containers at possible sites in Kandang Limun village is higher than the CSs. The high percentage of DSs that are positive for larvae is because DSs are a type of landfill that cannot control and are usually found outside the house and cannot use in households. However, when filled with rainwater, they can become mosquito breeding sites if not cleaned or buried. The results of this study are like those of Taslisia, $432 \mathrm{CSs}$, of which $81(18 \%)$ were positive for larvae and 126 DSs of which 42 (33\%) contained Aedes sp.

Positive container for Aedes sp. in Bentiring village consists of $63(66 \%)$ containers outside the house and $33(34 \%)$ containers inside the house. The results showed that most of the larvae of Aedes sp. found in containers located outside the house. There were 348 CSs in this study, with 67 (19\%) positive for larvae. In 
contrast, the DSs were 71 containers with $29(40 \%)$ positive for Aedes sp. larvae containers outside the house is a type of landfill that cannot be DS. The DSs are not used routinely in households, and the open conditions can become a breeding ground for mosquitoes when filled with rainwater. This condition is presumably because containers outside the house tend to be neglected and rarely cleaned, which can be a medium for the attachment of Aedes sp. mosquito eggs at the landfill.

Factors that can affect the high value of the $\mathrm{LI}$ $(\mathrm{HI}, \mathrm{Cl}$, and $\mathrm{BI})$ in Bentiring village are the behavior and participation of each house that is still lacking in breeding site eradication (PSN) activities. The characteristics of the container can also affect the presence of Aedes sp. A similar study conducted by Leri in Kupang city showed that active community participation had an important influence in reducing larval density [34]. According to the Ministry of Health of Indonesia, the 3M Plus PSN program is draining, closing, and utilizing used goods or recycling, larvicidation, biological control by raising larvae eating fish and using personal protective equipment, mosquito nets, and mosquito repellents [35].

A total of $89 \%$ of houses that were positive for larvae did not use larvicides. In this study, the Aedes sp. larva more eggs in containers that do not contain larvicides. Normal distribution of larvicides accompanied by evaluation of the effectiveness of insecticide is one solution to reduce the population of Aedes sp. The results of Jaya's research showed that a significant difference between the declines in larvae after abatement was carried out in dengue-endemic areas in the Somba Opu district, Gowa Regency.

The characteristics of containers in both villages are dominated by containers made of plastic (71.8\%), plastic containers that are positive for Aedes sp. larvae as much as $87 \%$. The use of water storage containers in the two villages has shifted from using bathtubs to buckets that are more practical, lighter, easier to move, and easier to obtain. In this study, positive containers for larva were dominated by dark-colored containers, which was $79 \%$. Containers that contain lots of water are a favorite place for Aedes sp. Because it can provide a sense of security and calm to lay the eggs, containers that can hold much water also make the water's surface darker. The dark color of the container also affects the density of larvae because dark containers are preferred as a breeding ground for light-colored ones; dark-colored containers tend to be places that make mosquitoes comfortable to lay eggs [36].

Most respondents collect as much clean water as possible for their daily needs in water reservoirs such as buckets, bathtubs, and drums. According to the WHO, stagnant clean water can be a breeding ground for Aedes sp. Aedes sp. can incubate their eggs in water reservoirs to become larvae. Tightly closing the water reservoir is essential in reducing the number of Aedes $s p$. larvae in the landfill. The results of a similar study by Sumantri showed a significant relationship between the habit of closing the landfill and the endemicity of dengue [32].

The survey results in the field showed that the percentage of positive larvae was higher in houses whose water source came from pump well water than houses whose water source came from government drinking water companies. There were $47 \%$ of containers with pump well water sources from 96 positive containers of larvae. Larval growth of Aedes sp. requires organic substances in the water as food and coupled with a temperature that supports the temperature of $20-30^{\circ} \mathrm{C}$. This container is fulfilled from dug/artistic well water, which contains a lot of organic substances produced by bacterial activity in the soil layer [37].

The determination of the $\mathrm{Ml}$ category relates to the number of CSs and DSs that determine the house is clean/unclean and high/low risk as a breeding ground for mosquitoes [38]. The number in each house is proportional to the $\mathrm{BRI}$ and $\mathrm{HRI}$ values, so the higher the $\mathrm{BRI}$ value, the higher the risk as a breeding ground for mosquitoes, and the higher the HRI value, the dirtier the status of the area. The higher the MI, the higher the potential for dengue incidence in the area.

Statistically, there is a significant relationship between the incidence of dengue and the MI in Bentiring and Kandang Limun villages. In this study, many residents' houses in the two villages have medium and high HRI and BRI values, have a high number of $\mathrm{CS}$, and are at risk as mosquito breeding places. It is necessary to pay attention to the cleanliness of water reservoirs from both CSs and DSs. This result is like Novia Rokhmawanti's research in Tegal Sari village, which shows a relationship between the $\mathrm{Ml}$ and the incidence of DHF in Tegal Sari village. Eradication of mosquito nests must continue to be improved to minimize water reservoirs used as breeding places for mosquitoes. Therefore, reducing the number of water reservoirs outside the home can significantly reduce mosquito population density [40], [41], [42].

The limitation of this study is that the research area is not wide because this is a preliminary study to build a vulnerability index of an area and spatial distribution to dengue [38], [43]. One of the factors that influence dengue cases is environmental factors.

\section{Conclusion}

In summary, based on the entomological parameters and Maya Index, Bentiring and Kandang Limun villages have a high risk of dengue transmission. Increase education about potential places for mosquito breeding, especially in wild places, because it can increase dengue cases. Suggestions to the community 
to further increase environmental awareness and promote cooperation regularly to eradicate mosquito nests both inside and outside the home as a step to prevent dengue transmission.

\section{Acknowledgments}

The authors would like to thank the Faculty of Medicine and Health Sciences, Bengkulu University, for funding the research, Bengkulu City Health Office, Community Health Centers, Bentiring villages, and Kandang Limun villages, Bengkulu city, for the cooperation.

\section{References}

1. CDC. Surveillance and Control of Aedes aegypti and Aedes albopictus in the United States, Surveill Control. Atlanta, Georgia, United States: CDC; 2017. p. 1-16.

2. WHO. Comprehensive Guidelines for Prevention and Control of Dengue and Dengue Haemorrhagic Fever. Geneva: WHO Regional Publication SEARO; 2011. p. 1-195.

3. Permatasari DY, Ramaningrum G, Novitasari A. Relationship between nutritional status, age, and gender with the degree of dengue infection in children. Muhammadiyah Med $\mathrm{J}$. 2015;2(1):24-8.

4. Health Office of Bengkulu City. Bengkulu City Health Profile 2017. Indonesia: Health Office of Bengkulu City; 2017. https:// doi.org/10.21475/ajcs.17.11.05.p317

5. Kurniati A, Triana D, Sulistiyorini EN, Sariyanti M, Wirastari GG. Association between body mass index and type of infection on the severity of dengue infection in Bengkulu city, Indonesia. Jumantik. 2021;6(3):225-33.

6. Health Office of Bengkulu City. Monthly Report of Bengkulu City DHF Patients in 2019. Indonesia: Health Office of Bengkulu City; 2019. https://doi.org/10.21475/ajcs.17.11.05.p317

7. Fabrizio C, Lepore L, Chironna M, Angarano G, Saracino A. Dengue fever in travellers and risk of local spreading: Case reports from Southern Italy and literature update. New Microbiol. 2017;40(1):11-8.

PMid:28072887

8. WHO. Guidelines for laboratory and field testing of mosquito larvicides. In: World Health Organization Communicable Disease Control, Prevention and Eradication WHO Pesticide Evaluation Scheme. Geneva: WHO; 2005. p. 1-41.

9. Taslisia T, Rusjdi SR, Hasmiwati H. Entomological survey, maya index, and susceptibility status of Aedes aegypti larvae against temephos. Andal Health J. 2018;7(1):33-41. https://doi. org/10.25077/jka.v7.i1.p33-41.2018

10. Widjajanti W, Ayuningtyas RT, Adnyana NW. Entomological index of dengue hemorrhagic fever vectors in three districts in Bali province. J Dis Reserve Vector. 2019;11(1):11-20. https:// doi.org/10.22435/vk.v11i1.1137

11. Hidayati L, Hadi UK, Soviana S. Utilization of ovitrap in population measurement of Aedes Sp. and determining the condition of the house. Indones J Entomol. 2017;14(3):126-34.
12. Latifa KN, Arusyid WB, Iswidaty T, Sutiningsin D. The effect of ovitrap as monitoring the presence of Aedes Sp. vector in Bulusan village, Tembalang district, Semarang city. IIm Mhs. 2013;3(1):26-9.

13. Wijayanti SP, Anandari D, Maghfiroh AF. Measurement of Ovitrap Index (OI) as a description of Mosquito Density in an Endemic Area of Dengue Hemorrhagic Fever (DHF) Banyumas Regency. Indones J Pub Health. 2017;5:56-63. https://doi. org/10.20884/1.ki.2017.9.1.228

14. Irwan I. Epidemiology of Infectious Diseases. Effect of Health Service Quality. $1^{\text {st }}$ ed., Vol. 109. Yogyakarta, Indonesia: CV Absolute Media; 2017. p. 109-19.

15. Dahlan MS. Sample Size and Method of Sampling in Health Medicine Research. $4^{\text {th }}$ ed. Indonesia: Epidemiologi Indonesia; 2016. 105-20.

16. Service M. Mosquito Ecology: Field Sampling Methods. $2^{\text {nd }}$ ed United Kingdom: Elsevier; 2008. p. 1-75.

17. FEHD. Dengue Fever and Vector Surveillance. The Food and Environmental Hygiene Department. Hong Kong: FEHD; 2017.

18. WHO. Review of Entomological Sampling Methods and Indicators for Esearch and Training in Tropical Diseases. Geneva: WHO; 2003.

19. Focks DA, Alexander N. Multicountry Study of Aedes aegypti Pupal Productivity Survey Methodology. Geneva, Switzerland: WHO; 2006. p. 7-56.

20. Health Office of Bengkulu City. Bengkulu City Health Profile 2018. Indonesia: Health Office of Bengkulu City; 2019. p. 88-110.

21. Dinata A, Dhewantara PW, Beberapa T, Tenggara A, Timur M. Characteristics of the physical, biological, and social environment in Dengue Endemis areas, Banjar city, 2011. J Health Eco. 2012;11(4):315-26.

22. Anoopkumar A, Puthur S, Varghese P, Rebello S, Aneesh EM Life cycle, bio-ecology and DNA barcoding of mosquitoes Aedes aegypti (Linnaeus) and Aedes albopictus (Skuse). J Commun Dis. 2017;49(3):32-41.

23. Khairunnisa $U$, Wahyuningsih NE, Hapsari. Density of Aedes $\mathrm{Sp}$. larvae (house index) as an indicator of dengue hemorrhagic fever vector surveillance in Semarang city. J Public Health. 2017;5(5):906-10.

24. Pagani G, Zanchetta N, Galimberti L, Oreni L, Passerini S, Giacomelli A, et al. Imported dengue fever: A 16-years retrospective analysis in milan (italy) and a brief review of the european literature. Infez Med. 2020;28(2):243-52. PMid:32487790

25. Baymakova M, Popov GT, Andonova R, Kovaleva V, Dikov I, Plochev K. Fever of unknown origin and Q-fever: A case series in a Bulgarian hospital. Caspian J Intern Med. 2019;10(1):102-6. https://doi.org/10.22088/cjim.10.1.102 PMid:30858949

26. Triana D, Siregar FN, Utami EP, Suteky T, Wicaksono S. Entomological parameters and characterization of insecticide resistance in dengue vector Aedes aegypti larvae from Bengkulu city, Indonesia. Malaysian J Public Health Med. 2021;21(1):96-102.

27. Cahyani IP. Incidence of Dengue Hemorrhagic Fever (DHF) in Magetan District, Magetan Regency in 2018, Thesis. Indonesia: Health Polytechnic Ministry of Health Surabaya; 2019. p. 25-35.

28. Anggraini $S$. The existance of larvae and dengue fever incidence in Kedurus sub-district in Surabaya. Environ Health J. 2018;10(3):252.

29. Firmansyah NE, Aulung A, Subahar R, Wibowo H, Sukri N Density of Aedes Sp. and its relationship to habitat factors in patunas village, tungkal ilir subdistrict, tanjung jabung Barat district. Indones Med J. 2019;7(2):1-7.

30. Agustin I. Egg-laying behavior and life cycle of Aedes aegypti in 
various water media. J Biol. 2017;6(4):71-81.

31. Jaya DM, Ibrahim EA. Relationship of Dengue Mosquitos Nest Eradication with the Presence of Aedes aegypti Larvae in the DHF Endemic Area of Kassi-Kassi, the City of Makassar. Indonesia: Fakultas Kesehatan Masyarakat Universitas Hasanuddin; 2012. p. 1-12.

32. Sumantri R, Hasibuan P, Novianry V. The relationship between mosquito nest eradication and family habits with the incidence of dengue hemorrhagic fever (DHF) in Pontianak city in 2013. J Untan. 2014;1(1):1-21.

33. Minhas S, Sekhon H. Entomological survey for dengue vector in an institutional campus to determine whether potential of dengue outbreak exixts. Int J Med Appl Sci. 2013;2(4): 164-71.

34. Leri CY, Setyobudi A, Ndoen EM. Density figure of Aedes aegypti larvae and community participation in prevention of dengue hemorrhagic fever (DHF). Lontar J Community Health. 2021;3(3):123-32.

35. Ministry of Health of Indonesia. Implementation of the Eradication of Mosquito Nests with the One House One Movement (JUMANTIK). Vol. 1. Indonesia: Ministry of Health of Indonesia; 2016.

36. Hoedojo R, Sungkar S. Morphology, life cycle and behavior of mosquitoes. In: Medical Parasitology. $4^{\text {th }}$ ed. Indonesia: Fakulty of Medicine Universitas Indonesia Press; 2013. p. 250-65.

37. Pratiwi TY, Anwar MC, Utomo B. Correlation between the characteristics of water reservoirs and community behavior with the presence of Aedes aegypti larvae in Karangklesem village,
South Purwokerto district, 2016. Community Environ Health Bull. 2018;37(1):56-61.

38. Rogers DJ, Suk JE, Semenza JC. Using global maps to predict the risk of dengue in Europe. Acta Trop. 2014;129(1):1-14. https://doi.org/10.1016/j.actatropica.2013.08.008 PMid:23973561

39. Praptowibo W. Maya index and overview of Aedes Sp. larvae breeding habitats. Based on DHF endemicity in Semarang City, Central Java province. J Pub Health. 2015;3:75-85.

40. Rokhmawanti N, Ginanadjar P, Martini M. The relationship between maya index and the incidence of dengue hemorrhagic fever in Tegalsari village, Tegal city. J Pub Health. 2015;3(1):162-70.

41. Martini M, Annisa J, Saraswati LD, Hestiningsih R, Kusariana N, Yuliawati S. Larvae density and environmental condition as risk factors to dengue incidence in Semarang city, Indonesia. In: IOP Conference Series: Earth and Environmental Science; 2019. p. 1-7.

42. Martini M, Armen Z, Nissa K, Retno H, Sri Y, Atik M, et al. Entomological status based on vector density index and transovarial infection on Aedes Sp. mosquito in Meteseh village, Semarang city. In: E3S Web of Conferences; 2020. p. 1-8.

43. Amir M, Hussain A, Asif M, Ahmed S, Alam H, Moga MA, et al. Full-length genome and partial viral genes phylogenetic and geographical analysis of dengue serotype 3 isolates. Microorganisms. 2021;9(2):323. https://doi.org/10.3390/ microorganisms 9020323

PMid:33557307 